\title{
ARCS Kategorileri İle Bütünleşmiş Bilişsel Öğrenme Modelinin Öğrencilerin Çokgenler ve Üçgenler Konusundaki Öğrenme Düzeylerine ve Motivasyonlarına Etkisi
}

\author{
Ahsen FİLİz ${ }^{1}$, Hülya GÜR ${ }^{2}$ \\ ${ }^{1}$ Balıkesir Üniversitesi, Fen Bilimleri Enstitüsü, Balıkesir, ahsenayanayan@gmail.com, \\ http://orcid.org/000-0002-8886-5572 \\ 2 Balıkesir Üniversitesi, Necatibey Eğitim Fakültesi, Balıkesir, hgur@balikesir.edu.tr, \\ http://orcid.org/0000-0001-8479-8811
}

Gönderme Tarihi: 01.04.2021

Kabul Tarihi: 21.04 .2021

Doi: $10.17522 /$ balikesirnef.907736

Özet - Bu araştırmada, ARCS kategorileri ile bütünleşmiş bilişsel öğrenme modelinin beşinci sınıf öğrencilerin çokgenler ve üçgenler konusundaki öğrenme düzeylerine ve motivasyonlarına etkisinin belirlenmesi amaçlanmıştır. Araştırmada son test kontrol gruplu model kullanılmıştır. Deney grubu 137 ve kontrol grubu 137 öğrenciden oluşmuştur. Deney grubu öğrencilerine, çokgenler ve üçgenler konusu ARCS kategorileri ile bütünleşmiş bilişsel öğrenme modeline dayalı olarak, kontrol grubu öğrencilerine geleneksel öğretim yöntemine dayalı olarak işlenmiştir. Araştırmada, geometri başarı testi ve geometri kavram algılama testi kullanılmış ve geometri motivasyon ölçeği ve geometri motivasyon profili ölçeği geliştirilerek veriler toplanmıştır. Verilerin analizinde $t$ testinden yararlanılmıştır. Araştırma verilerinin analizi sonucunda, deney grubu öğrencilerinin kontrol grubu öğrencilerine göre başarı ve kavram algılama düzeylerinin daha yüksek olduğu görülmüştür. Kontrol grubundaki öğrencilerin deney grubundaki öğrencilere kıyasla geometri dersinde kendilerini yetersiz gördüğü ve korkularının daha fazla olduğu tespit edilmiş̧ir. Diğer bir sonuç ise deney grubu öğrencilerinin kontrol grubu öğrencilerine kıyasla doyum puanlarının yüksek olması ve geometri dersine yönelik dikkatlerinin daha fazla olmasidır.

Anahtar kelimeler: ARCS kategorileri, Bilişsel öğrenme modeli, başarı düzeyi, kavram algılama düzeyi, motivasyon

Sorumlu yazar: Ahsen FíLiZ, Balıkesir Üniversitesi, Fen Bilimleri Enstitüsü, Balıkesir, Türkiye. Birinci yazarın doktora tezinden üretilmiştir. 


\section{Geniş Özet}

\section{Giriş}

Geometri dünya çapında önemli bir alan olup birçok bilim dalında yaygın olarak kullanılmaktadır. Geometride, matematikte olduğu gibi öğrenciler farklı bakış açıları sayesinde problemleri analiz ederek çözebilir, ilişkiler kurup soyut kavramları geometrik gösterimler yoluyla daha basit şekilde anlaşılır kılabilir. Öğrenciler ilköğretim üçüncü sınıfta geometri ile tanışmakta ve öğretim yıllarının ilerlemesi ile geometri ile ilgili kavramları daha karmaşık bir şekilde öğrenmektedir. Burada önemli olan öğrencilerin olası bir yanlış kavrama ve hataya düşmemeleri için geometrik kavramları hiyerarşik bir sıra halinde öğrenmeleri gerektiğidir. Öğrenciler ilköğretim düzeyinde iken geometri öğretimi iyi kavratılmaz ise ortaöğretim düzeyinde geometri öğretiminde büyük sıkıntılar meydana gelebilir. Ülkemizde geometri alanında yeterli çalışma bulunmamasına rağmen, yapılmış olan çalışmalardan geometri öğretiminin öğrenciler tarafından anlaşılmasının büyük bir problem olduğu bilinen bir gerçektir.

\section{ARCS Motivasyon Modeli}

Keller, bu motivasyon modelini öğrencilerin öğrenme ortamlarında motivasyonlarını sağlayarak sürekliliğini ortaya koyan ve öğrencileri motive edecek ortamları tasarlayan bir model olarak tanımlamıştır (Keller, 1983). Keller'in ARCS Motivasyon Modelinin öğretim alanına en önemli katkısı, modelin yalnızca güdüleme kategorilerinin belirlenmesi ve sınıflandırılması ile kalmayıp her kategori ve alt kategorilere ilişkin öğretim stratejilerine de yer verilmiş olmasıdır. Bu şekilde ARCS Motivasyon modeli öğretim alanlarında daha kolay bir şekilde kullanılabilecek ve her alt stratejide öğrenci özelliklerinin tanımlanması sağlanacaktır (Tahiroğlu, 2015).

\section{Bilişsel Öğrenme Modeli}

Bilişsel Öğrenme Modeli (Öğe Gösterim Teorisi) Merrill (1983) tarafından bir kavramı, ilkeyi veya işlemi öğreterek öğrencilerin öğrenme kapasitelerini arttırmak için geliştirilen bir öğretim teorisidir. Literatürde Öğe Gösterim Teorisi olarak adlandırılmakta olup yalnızca bilişsel öğrenmeleri içeren ve mikro düzey stratejileri ile ilgilenen bir kuram olduğu için araştırmacı tarafından çalışmada bilişsel öğrenme modeli olarak adlandırılmıştır. Bilişsel öğrenme alanı ile sınırlandırılıp duyuşsal ve psikomotor öğrenme alanlarını kapsamadığı için 
model öğretmen ve öğretim tasarımcılarına daha çok rehberlik olanağı sağlamaktadır (Dede, 2003).

Çalışmada ARCS kategorileri ile bütünleşmiş Bilişsel öğrenme modeli bir arada kullanılarak öğrencilerin çokgenler ve üçgenler konusundaki öğrenme düzeylerine ve motivasyonlarına etkisini ortaya koymak amaçlanmıştır. $\mathrm{Bu}$ amaç doğrultusunda aşağıdaki problemlere yanıt aranmıştır;

1. ARCS kategorileri ile bütünleşmiş bilişsel öğrenme modeli uygulanan deney grubu öğrencileri ile geleneksel öğretim uygulanan kontrol grubu öğrencilerin geometri başarı düzeyleri arasında anlamlı bir fark var mıdır?

2. ARCS kategorileri ile bütünleşmiş bilişsel öğrenme modeli uygulanan deney grubu öğrencileri ile geleneksel öğretim uygulanan kontrol grubu öğrencilerin kavram algılama düzeyleri arasında anlamlı bir fark var mıdır?

3. ARCS kategorileri ile bütünleşmiş bilişsel öğrenme modeli uygulanan deney grubu öğrencileri ile geleneksel öğretim uygulanan kontrol grubu öğrencilerin geometri motivasyon puanları arasında anlamlı bir fark var mıdır?

4. ARCS kategorileri ile bütünleşmiş bilişsel öğrenme modeli uygulanan deney grubu öğrencileri ve geleneksel öğretim uygulanan kontrol grubu öğrencilerinin son test geometri motivasyon profili puanları arasında anlamlı fark var mıdır?

\section{Yöntem}

\section{Araştırma Modeli}

Araştırmada son test kontrol gruplu model kullanılmıştır (Büyüköztürk, Çakmak, Akgün, Karadeniz ve Demirel, 2012). ARCS kategorileri ile bütünleşmiş bilişsel öğrenme modeli uygulanan öğrenciler deney grubu, geleneksel öğretim modeli uygulanan öğrenciler kontrol grubu olarak seçilmiştir. Bu gruplar yansız bir seçimle oluşturulmuştur. Grupların her ikisine de deney sonrası son test uygulanmıştır. Deneysel çalışma öncesi grupları benzer olduğu gruplar arası farklılık olmadığı kabul edilmiştir (Karasar, 2012).

\section{Çalışma Grubu}

Çalışma grubu 2020-2021 eğitim-öğretim yılında Kırklareli ilinin Lüleburgaz ilçesinde bulunan 274 5. sınıf öğrencisidir. Bu kapsamda 137 öğrenci deney grubu 137 öğrenci kontrol grubunu oluşturmuştur. Çalışma grubunu oluşturan öğrenciler tesadüfi örnekleme yöntemi ile belirlenmiştir. 


\section{Veri Toplama Araçları}

$\mathrm{Bu}$ çalışmada öğrencilerin çokgenler ve üçgenler konusundaki başarı ve motivasyon düzeylerini belirlemek için Geometri başarı testi ve Geometri motivasyon ölçeği kullanılmıştır. Uygulama için Milli Eğitim Bakanlığı'ndan gerekli izinler alınmıştır.

\section{Verilerin Analizi}

Veriler SPSS 21.0 paket programı kullanılarak analiz edilmiştir. Deneysel işlem sonrası ARCS kategorileri ile bütünleşmiş Bilişsel öğrenme modeli uygulanan deney grubu ile geleneksel öğretim uygulanan kontrol grubunun başarı düzeyleri ve kavram algılama düzeylerinde anlamlı farklılık olup olmadığını belirlemek için t-testi yapılmıştır. ARCS kategorileri ile bütünleşmiş Bilişsel öğrenme modeli uygulanan deney grubu ve geleneksel öğretim uygulanan kontrol grubunun motivasyon ölçeği alt boyutları ve motivasyon profili ölçeği alt boyutlarına ilişskin farkın anlamlılığını tespit etmek için t-testi uygulanmıştır.

\section{Bulgular}

$\mathrm{Bu}$ bölümde deneysel işlem sonrasında toplanmış olan verilerin istatistiksel çözümlemelerine ilişkin araştırma sonucunda elde edilen bulgular yer almaktadır.

\section{Deney ve kontrol grubu ögrencilerinin geometri başarı düzeylerine ilişkin bulgular}

ARCS kategorileri ile bütünleşmiş bilişsel öğrenme modeli uygulanan deney grubu öğrencileri ile geleneksel öğretim yöntemi uygulanan kontrol grubu öğrencilerinin çokgenler ve üçgenler başarı testi puan ortalamaları farklılık göstermektedir. ARCS kategorileri ile bütünleşmiş bilişsel öğrenme modeli uygulanan deney grubu öğrencilerinin geleneksel öğretim yöntemi uygulanan kontrol grubu öğrencilerine göre başarı düzeyinin daha yüksek olduğunu göstermektedir.

\section{Deney ve kontrol grubu ögrencilerinin kavram algılama düzeylerine ilişkin bulgular}

ARCS kategorileri ile bütünleşmiş bilişsel öğrenme modeli uygulanan deney grubu öğrencileri ile geleneksel öğretim yöntemi uygulanan kontrol grubu öğrencilerinin çokgenler ve üçgenler kavram algılama testi puan ortalamaları farklılık göstermektedir. ARCS kategorileri ile bütünleşmiş bilişsel öğrenme modeli uygulanan deney grubu öğrencilerinin geleneksel öğretim yöntemi uygulanan kontrol grubu öğrencilerine göre kavram algılama düzeyinin daha yüksek olduğunu göstermektedir. 


\section{Deney ve kontrol grubu ögrencilerinin motivasyon düzeylerine ilişkin bulgular}

Geleneksel öğretim yöntemi uygulanan kontrol grubundaki öğrencilerin ARCS kategorileri ile bütünleşmiş bilişsel öğrenme modeli uygulanan deney grubu öğrencilerine göre geometri dersine yönelik kendini yetersiz görmeleri ve geometri dersine yönelik korkuları daha yüksektir.

\section{Deney ve kontrol grubu ögrencilerinin motivasyon profili düzeylerine ilişkin bulgular}

ARCS kategorileri ile bütünleşmiş bilişsel öğrenme modeli uygulanan deney grubu öğrencilerinin geleneksel öğretim yöntemi uygulanan kontrol grubu öğrencilerine göre geometri dersine yönelik dikkatlerinin daha fazla olduğu görülmektedir. Ayrıca kontrol grubundaki öğrencilerin deney grubundaki öğrencilere kıyasla edindikleri deneyimlere bağl1 olumlu düşünceleri daha fazladır.

\section{Sonuç ve Tartışma}

Çalışmaya katılan öğrencilerin çokgenler ve üçgenler konusundaki başarı düzeylerine ilişkin bulgular incelendiğinde, ARCS kategorileri ile bütünleşmiş bilişsel öğrenme modeli yaklaşımı uygulanan deney grubu öğrencilerinin geleneksel öğretim uygulanan kontrol grubu öğrencilerine göre çokgenler ve üçgenler konusu öğreniminde daha başarılı oldukları ortaya çıkmıştır. Ayrıca ARCS kategorileri ile bütünleşmiş bilişsel öğrenme modelinin konunun öğrenilmesinde etkili olduğu olumlu yönde sonuç verdiği söylenebilir. Bu çalışmanın sonuçlarına benzer Dede (2003) tarafından yapılan araştırmada da görülmektedir. Dede (2003) çalışmasında ARCS Motivasyon Modeli ve Öğe Gösterim Teorisine dayalı yaklaşımın değişken kavramının öğrenci başarısına etkisinin olup olmadığını araştırmış ve araştırma sonucunda öğrencilerin öğrenme düzeyleri bakımından deney grubu lehine anlamlı bir farklılık elde etmiştir. Aynı şekilde Yeşiltepe (2019) ve Narmanlı (2019)'da çalışmalarında ARCS Motivasyon modeline göre tasarlanmış bir öğretim uygulayarak öğrenci başarısını incelemiş ve çalışma sonucunda modelin akademik başarıyı arttırdığg sonucu elde edilmiştir. Bu araştırmalar çalışmanın bulguları ile paralellik göstermektedir.

Çalışmaya katılan öğrencilerin çokgenler ve üçgenler konusundaki kavram algılama düzeylerine ilişkin bulgular incelendiğinde, ARCS kategorileri ile bütünleşmiş bilişsel öğrenme modeli yaklaşımı uygulanan deney grubu öğrencilerinin geleneksel öğretim uygulanan kontrol grubu öğrencilerine göre çokgenler ve üçgenler konusunda kavram algılama düzeylerinin daha 
yüksek olduğu söylenebilir. Yani, ARCS kategorileri ile bütünleşmiş bilişsel öğrenme modeli öğrencilerin konuyu kavramasında olumlu yönde sonuç göstermiştir.

Çalışmaya katılan öğrencilerin geometri dersi motivasyon düzeylerine ilişkin bulgulara bakıldığında, geometri motivasyon ölçeği alt boyutları olan geometri yetersizliği ve geometri korkusu puan ortalamalarında istatistiksel olarak anlamlı fark ortaya çıkmıştır. Geleneksel öğretim yöntemi ile öğrenim gören kontrol grubu öğrencilerinin geometri dersinde kendini yetersiz gördüğü söylenebilir. Ayrıca geleneksel öğretim yöntemi ile öğrenim gören kontrol grubu öğrencilerinin ARCS kategorileri ile bütünleşmiş bilişsel öğrenme modeli yaklaşımı ile öğrenim gören deney grubu öğrencilerine kıyasla geometri dersine yönelik korkularının daha fazla olduğu söylenebilir. Benzer olarak Balantekin ve Bilgin (2017) çalışmasında ARCS Motivasyon Modelinin öğrencilerin motivasyon düzeylerini etkilediği sonucuna ulaşmıştır. Narmanlı (2019)'da yaptığı araştırmada benzer bulgulara ulaşmıştır. Çalışmasında ARCS Motivasyon Modelinin öğrencilerin motivasyon düzeyine etkisini incelemiş ve modelin öğrencilerin motivasyonunu arttırdığını, süreçte öğrencileri aktif kıldığını ve süreç boyunca öğrencilerin dikkatinin korunduğunu tespit etmiştir. ARCS Motivasyon Modelinin öğrenci motivasyonuna etkisinin olmadığı sonucuna ulaşan çalışmalarda mevcuttur. Örneğin, Dede (2003) araştırmasında ARCS Motivasyon Modelinin öğrencilerin matematik dersine yönelik motivasyon etkisini incelemiş ve öğrencilerin motivasyon son test puanları arasında anlamlı bir fark olmadığını tespit etmiştir.

Öğrencilerin geometri dersi motivasyon profili etkisine ilişkin bulgulara göre geometri motivasyon profili ölçeği alt boyutları doyum ve dikkat puan ortalamalarında istatistiksel olarak anlamlı fark saptanmıştır. Geleneksel öğretim yöntemi ile öğrenim gören kontrol grubu öğrencilerinin geometri dersine yönelik doyum puanları daha yüksektir. Ayrıca deney grubu öğrencilerinin derste dikkatini sürdürme konusunda kontrol grubu öğrencilerine göre daha başarılı oldukları söylenebilir. Dinçer (2020) motivasyon ile ARCS modeline göre tasarlanan materyaller arasında ilişkiyi inceleyen bir meta-analiz çalışması yapmış ve çalışma sonucunda materyallerin motivasyon üzerinde olumlu etkisi olduğu sonucuna ulaşmıştır. Materyal kullanım süresinin artması ile öğrencilerin motivasyonunun arttığını tespit etmiştir. Koon Wah (2015) çalışmasında, dikkat, ilişki, güven ve doyum stratejilerini entegre ederek Geogebra kullanıp öğretim yapmış ve lise öğrencilerinin motivasyon ve başarılarına etkisini araştırmıştır. Öğretim öncesi ve sonrası öğrencilerin motivasyon ve başarısında anlamlı farklılık tespit etmiştir. Bu araştırmalar modelin motivasyon üzerinde olumlu etkisinin olduğunu göstermekte ve çalışmanın bulguları ile örtüşmektedir. 
Özetle, bu çalışmanın bulguları doğrultusunda beşinci sınıf öğrencilerinin çokgenler ve üçgenler konusunun öğretiminde uygulanan ARCS kategorileri ile bütünleşmiş bilişsel öğrenme modeli yaklaşımının öğrenme düzeyinde mevcut öğretim yöntemine kıyasla daha etkili olduğu ve motivasyonu olumlu yönde etkilemiştir. Çokgenler ve üçgenler konusunun birçok matematiksel kavramı ve geometrik öğeleri barındırması, ARCS kategorileri ile bütünleşmiş bilişsel öğrenme modelinin bir öğretim ortamında kullanılarak öğrenci motivasyonunun sağlanıp devam ettirilmesi ve göz ardı edilen güdüleme boyutunun ele alınması çalışmanın önemini ön plana çıkarmakta olduğundan literatüre ve teoriye katkı sağlayacaktır.

\section{Öneriler}

$\mathrm{Bu}$ araştırma sonuçları göz önüne alınarak eğitimciler ve araştırmacılara modelin çalışma örneklerine az rastlanıldığı için bu konuda daha fazla çalışma yapılması önerilebilir. Modelin farklı derslerde ve farklı sınıf düzeylerine uygulanarak etkisi araştırılabilir. Araştırmada, ARCS kategorileri ile bütünleşmiş bilişsel öğrenme modeli yaklaşımı uygulanarak öğrencilerin öğrenme düzeylerine ve motivasyonlarına etkisi incelenmiştir. $\mathrm{Bu}$ değişkenlerden farklı tutum, bilginin kalıcılığg gibi farklı değişkenler ele alınarak modelin etkisi araştırılabilir. Model geometri alanında farklı konulara uyarlanabilir. 


\title{
The Effect Of The Cognitive Learning Model Integrated With ARCS Categories On The Learning And Motivation Levels Of Students About Polygons And Triangles
}

\author{
Ahsen FİLİZ ${ }^{1}$, Hülya GÜR ${ }^{2}$ \\ ${ }^{1}$ Balikesir University, Science Institude, Balikesir, ahsenayanayan@gmail.com, \\ http://orcid.org/000-0002-8886-5572 \\ 2 Balikesir University, Necatibey Educational Faculty, Balikesir, hgur@balikesir.edu.tr, \\ http://orcid.org/0000-0001-8479-8811
}

Received : 01.04.2021

Accepted : 21.04 .2021

Doi: $10.17522 /$ balikesirnef.907736

\begin{abstract}
In this study, it is aimed to determine the effect of the integrated cognitive model of learning with ARCS categories on the learning and motivation levels of fifth grade students about polygons and triangles. The post-test control group model was used in the study. Both the experimental group and the control group consisted of 137 students. The subject of polygons and triangles was taught to the experimental group students based on the integrated cognitive model of learning with ARCS categories, and to the control group students based on the traditional method of teaching. In the present study, geometry achievement test and geometry concept perception test were used, and the data were collected by developing the geometry motivation scale and the geometry motivation profile scale. Thus, t test was utilized in the analysis of the data. As a result of the analysis of the research data, it was seen that the experimental group students had higher levels of achievement and concept perception compared to the control group students. Moreover, it was determined that the students in the control group considered themselves insufficient and had more fear towards geometry lessons compared to the students in the experimental group. Furthermore, the satisfaction scores of the experimental group students were higher and they paid more attention to the geometry lessons than the control group students accordingly.
\end{abstract}

Key words: ARCS categories, Cognitive model of learning, achievement level, concept perception level, motivation

Corresponding author: Ahsen FİLIZ, Balikesir University, Science Institude, Balikesir, Turkey. Produced from the first author's doctoral thesis. 


\section{Introduction}

Geometry is an important field worldwide and is widely used in many disciplines. In geometry, as in mathematics, students can analyse and solve problems from different perspectives, establish relationships and make abstract concepts more easily understood through geometric representations. Geometry learning begins at a very young age with the students examining their environments by familiarizing themselves with. Therefore they perceive the differences among the shapes by examining the objects they see in their environments and try to find the common aspects. As the age gets older, they go into the system more and continue their geometric thinking learning at a high level from the point of view of induction and deduction. While learning process continues, students may fall into many misconceptions and mistakes. Students are introduced to geometry in the third grade of elementary education and learn more complex concepts related to geometry as the school years progress. The students should learn geometric concepts in a hierarchical order in order to avoid any possible misunderstanding and mistake. If the teaching of geometry is not well understood while students are at primary education level, there may be serious problems in teaching geometry at secondary education level. Although there is not enough study in the field of geometry in our country, geometry teaching is rather difficult to be grasped by the students.

\section{ARCS Model of Motivation}

Motivation is a force initiates and directs behaviour and directly affects the success factor. Keller has done a lot of research on the topic of motivation. In 1987, he developed the ARCS Model of Motivation as a result of his studies on human motivation. Keller defined motivational model as a model that sets students' motivation in learning environments and designs environments that will motivate students (Keller, 1983). According to Keller (1987b), what is quintessential to boost people's motivation is the thing that students should figure out what the concept of motivation is and that the way to be followed in order to increase motivation should be planned and programmed while being transferred to the lesson environments.

The most important contribution of Keller's ARCS Motivation Model to the field of teaching is that the model is not only determined and classified by the motivation categories, but also includes teaching strategies for each category and subcategories. The ARCS Motivation Model will be used more easily in teaching areas and it will be provided to define student characteristics for each sub-strategy (Tahiroglu, 2015). ARCS motivation model strategies and sub-strategies are given in Table 1 below. 
Table 1 Strategies and sub-strategies of the ARCS Motivation Model

\begin{tabular}{|c|c|}
\hline $\begin{array}{l}\text { Strategies and Sub- } \\
\text { Strategies }\end{array}$ & Method Questions on Sub-Strategies in the Design Process \\
\hline $\begin{array}{l}\text { Attention } \\
\text { *erceptual } \\
\text { Arousal }\end{array}$ & How can I get students' attention? \\
\hline * Inquiry Arousal & What kind of attitude do I need to display to warn? \\
\hline * Variability & How can I keep the students' attention for a long time? \\
\hline $\begin{array}{r}\text { Relevance } \\
* \quad \text { Familiarity }\end{array}$ & $\begin{array}{l}\text { How can I provide the subjects that students will learn by adding my } \\
\text { own experiences? }\end{array}$ \\
\hline * Goal Orientation & How can I best identify the needs of the students? \\
\hline * Motive Matching & $\begin{array}{l}\text { How and in what way can I determine the time when students should } \\
\text { make choices and take responsibilities? }\end{array}$ \\
\hline $\begin{array}{l}\text { Confidence } \\
\text { Success } \\
\text { Opportunities }\end{array}$ & $\begin{array}{l}\text { How and in what way can I determine the time when students should } \\
\text { make choices and take responsibilities? }\end{array}$ \\
\hline * Personal Control & How can I ensure that students' expectations of success are positive? \\
\hline $\begin{array}{l}\text { *erformance } \\
\text { Requirements }\end{array}$ & $\begin{array}{l}\text { How can I explain that students need to use their efforts and abilities in } \\
\text { order to be successful? }\end{array}$ \\
\hline $\begin{array}{l}\text { Satisfaction } \\
\text { Intrinsic } \\
\text { Reinforcement }\end{array}$ & $\begin{array}{l}\text { How can I provide opportunities for students to apply their newly } \\
\text { acquired knowledge and skills? }\end{array}$ \\
\hline $\begin{array}{l}\text { Extrinsic } \\
\text { Rewards }\end{array}$ & How can I reward students' achievements by encouraging them? \\
\hline * Equity & $\begin{array}{l}\text { How can I help students to have a positive emotion in their } \\
\text { achievement? }\end{array}$ \\
\hline
\end{tabular}

Table 1 shows the questions about the strategies and sub-strategies of the ARCS Motivation Model. The explanations for each sub-strategy of the model are given below.

\section{Attention}

Attention is the model's first and most important strategy. In addition the attention strategy considers as attracting the students' attention at the beginning of the lesson and throughout the lesson. The attention strategy consists of three sub-strategies as follows:

1. Perceptual Arousal: It is to attract students' attention by making them curious, along with surprise and interesting environments. 
2. Inquiry Arousal: It is to ensure the continuity of the student's attention by revealing the problem situation (Keller, 1987a).

3. Variability: It is to use different methods and strategies in teaching in order to sustain students' interest towards the lesson and to prevent them from getting bored.

\section{Relevance}

Attention, interest and curiosity are indispensable but not sufficient to motivate students to the lesson. In addition to these, instruction must be consistent, clear and apprehensible with its goals for motivation. The relevance strategy consists of three sub-strategies (Keller, 1987a and Keller, 1987b) as follows:

1. Familiarity: The fact that the examples and concepts presented in the learning process are from the close environment enables students to be closer to the subjects (Kurt, 2012).

2. Goal Orientation: The goals, objectives of the lesson, explaining where and how to use the knowledge provide some orientation to the goal itself.

3. Motive Matching: It is not about what to teach the student, but rather how to teach it.

\section{Confidence}

The goal of the confidence strategy is to help students to feel positive by having positive expectations. Keller (1987a) explained the confidence strategy in three sub-strategies as follows:

1. Success Opportunities: It is the state of informing students about success and evaluation criteria.

2. Personal Control: Creating opportunities for students to be successful by setting goals according to their level of success.

3. Performance Requirements: It is to ensure that students achieve success by supporting their efforts and abilities.

\section{Satisfaction}

In the ARCS Motivation Model, the prerequisites for motivation in the learning process are attention, relevance and confidence strategies. The satisfaction strategy is that students have the necessary positive thinking in the process of gaining learning experience. Keller (1987a) explained the satisfaction strategy in three sub-strategies as follows: 
1. Intrinsic Reinforcement: It is to provide the opportunity to use students' newly acquired knowledge and skills in real or virtual situations help themselves to realize what they do and what kind of problems they ought to solve accordingly.

2. Extrinsic Rewards: It is the continuation of the desired behaviour by giving reinforcement and feedback in order to motivate the student to the lesson externally.

3. Equity: It is to ensure the conformity of the results together with the goals that emerge in order to achieve success (Keller \& Kopp, 1987).

\section{Cognitive Model of Learning}

Cognitive Model of Learning (Item Representation Theory) is a teaching theory developed by Merrill (1983) to increase students' learning capacity by teaching a concept, principle or process. It is named as Item Representation Theory in the literature and is named as Cognitive Learning Model in the current study by the researcher. Because the theory includes only cognitive learning and deals with micro-level strategies. Since it is limited to the cognitive learning area and does not include affective and psychomotor learning areas, the model provides more guidance opportunities for teachers and instructional designers as a result (Dede, 2003).

According to Merrill, Cognitive Learning Model is a theory developed in relation to the inadequacy and the highlighting approach in Gagne's Learning Hierarchy (1977) which is from the piece to the whole (Reigeluth, 1983, Reigeluth, 1987). Cognitive Learning Model is not a method based on the classification of achievement levels and content types, but a theory consisting of the components of teaching delivery. Cognitive Learning Model is a model consisting of three-phase forms with matrix representation as follows:

a) Two-dimensional performance-content (P/C) classification system,

b) Presentation forms (cognitive power forms),

c) Solutions created by the classification of presentation forms (relationship between forms).

Performance-Content Matrix representation is given in Figure 1 below. 


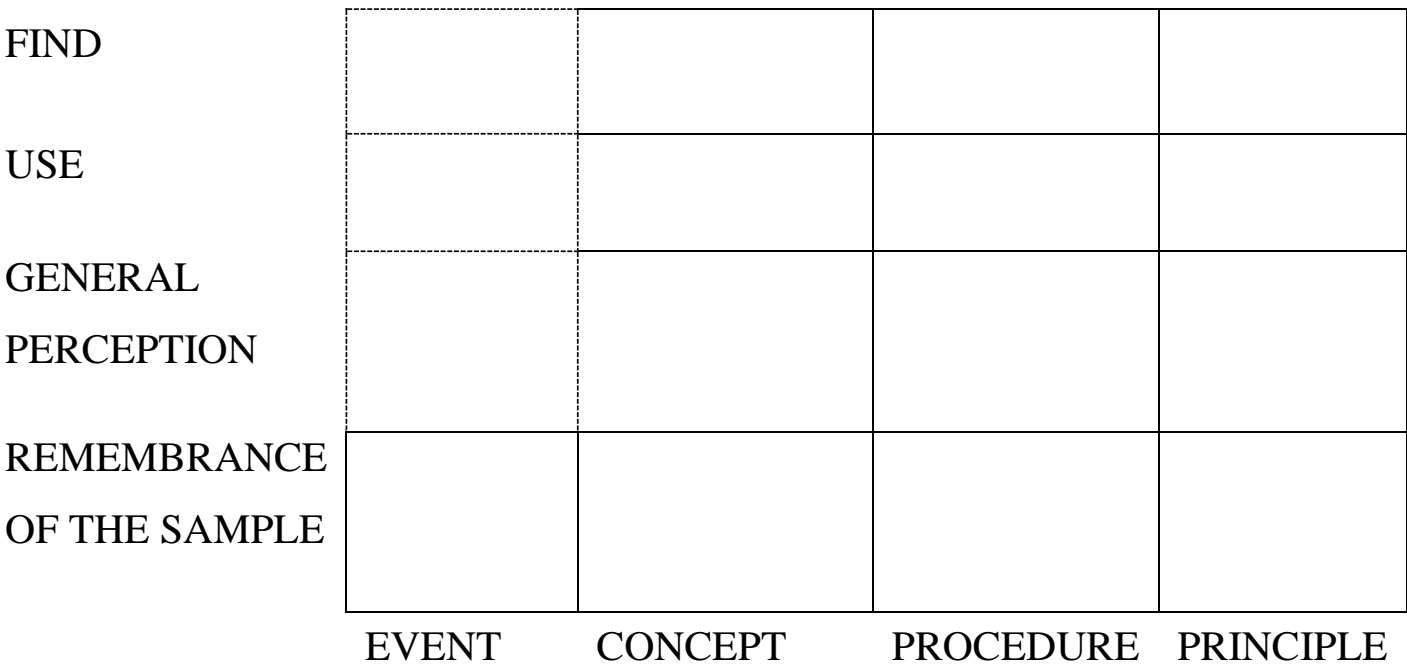

Figure 1: Representation of the Performance-Content Matrix (P/C).

The representation of the Performance-Content Matrix is given in Figure 1 above. The event, concept, procedure and principle components of the Performance-Content Matrix constitute the abscissa axis, while the components of remembrance of the sample, general perception, use and find constitute the ordinate axis. There is a relationship between the horizontal and vertical components against a point on the coordinate axis. For example, when the event component is taken on the abscissa, it is not possible to make a match with the components of find and use corresponding to the ordinate (Adir, 2011).

a) Performance-Content Matrix: While it does not include emotional and psychomotor factors, it presents a two-dimensional classification valid for cognitive results. These dimensions are as follows:

1. Student Success: Remembrance of the sample, general perception, using, finding.

2. Subject Content: Event, concept, procedure, principle (Merrill, 1987a; Merrill, 1987b).

b) Presentation Forms: Presentation forms are in four different forms as follows:

1. Primary presentation forms: It is a presentation form based on the principle of different results and the necessity of different learning situations proposed by Gagne.

2. Secondary presentation forms: It is a more detailed type of the primary presentation forms. First presentation forms are a basic tool used in teaching, while secondary presentation forms are a method used to facilitate the learner's process of structuring information (Merrill, 1983). 
3. Tertiary presentation forms: The process is includes how the presented information should be processed and how information should be considered accordingly.

4. Quaternary presentation forms: It covers the instructions on how to operate the equipment used while presenting materials to students.

c) Relationship Between Forms: It consists of relations related to the way the representation in the whole is affected by a different representation of the same size (Eryllmaz, 2009).

Consequently, geometry is an important tool in problem solving strategies, gaining knowledge and skills. Polygons and triangles are an important subject of geometry because they contain many mathematical concepts and geometric elements. Therefore, there are many studies on the teaching of polygons and triangles. For example, in his study, Budak (2010) examined the effect of geometry activities on polygons prepared with Geometer's Sketchpad on students' success in computer use, and as a result, it was revealed that processing the subject of polygons with computer-aided instruction affected students' success. Moreover, Fujita (2012) aimed to reveal the skills of teachers to define and classify quadrilaterals. At the end of the study, the research found teachers had difficulties in establishing relationships between quadrilaterals. Firstly students evaluated the quadrilaterals by thinking about the prototype patterns and shapes despite knowing their definitions. Furthermore, Bernabeu in his study with Moreno and Llinares (2021) investigated how students make sense of the concept of a polygon and the relationships between polygons. As a result of the study, he determined that learning the concept of a polygon depends on how students grasp the properties of the definition of a polygon.

In the literature, there are also studies that examine the effect of students' achievement and motivation by applying the ARCS Motivation Model. Balantekin (2014) analysed the effect of constructivist learning approach that was designed according to the ARCS Motivation Model on students' motivation, attitude and achievement and concluded that the motivational performances of students in the experimental and control groups differ in the intrinsic motivation dimension, and that the ARCS Motivation Model has a significant effect on increasing success. In addition, Lacinbay and Yilmaz (2019) used the ARCS Motivation Model in the course material development process, and as a result of the research, they found no significant difference in the attitude, motivation and curiosity levels of the students before the experimental process, but a significant difference was found in the attitude towards the lesson, motivation and knowledge-based curiosity after the experimental process accordingly. Moreover, Yeşiltepe (2019) investigated the effect of students' achievement and motivation by applying the learning approach that was designed according to the ARCS Motivation Model 
and revealed that the model increased student success considerably, but had no effect on motivation. It should be noted that considering the studies on the cognitive learning model, Eryllmaz (2009) aimed to reveal the effect of concept teaching that was designed according to the Item Representation Theory in the web environment on student achievement, attitude and learning retention. The study determined that the web-based student group to which applied the Item Representation Theory was more successful than the traditional teaching group. The students had higher attitudes towards the course and more successful in permanence measurements thus permanence in students' learning was made. Cevher (2019) investigated the effect of concept teaching based on Item Representation Theory on student achievement. The research stated that the student group which was taught the concept teaching based on Item Representation Theory was successful and students had a positive perspective towards the theory. Dinçer's (2020) study examined the relationship between motivation and materials that were designed and the study reached the conclusion of the ARCS model increased motivation. Chang, $\mathrm{Hu}$, Chianh, and Lugmayr (2019), on the other hand, aimed to verify the learning skills of students by applying the ARCS Motivation Model with mobile augmented reality technology and the experimental group students using mobile augmented reality technology showed a higher learning performance than the control group students accordingly. Last but not least, in his research, Koon Wah (2015) investigated the effects of students' achievement and motivation who have applied teaching with the Geogebra program by integrating the strategies of the ARCS Motivation Model. The study found there was a significant difference after the instruction he applied compared to the previous instruction as a result. It is essential that the studies conducted are studies that include a single model on the ARCS Motivation Model or Cognitive Learning Model. Hence, there are very few studies carried out dealing with the Geometry field. In the present study, it was aimed to reveal the effect of the Cognitive Learning Model integrated with ARCS categories on the learning levels and motivation of the students about polygons and triangles. The research questions are as follows:

1. Is there a significant difference between the geometry achievement levels of the experimental group students who were applied cognitive learning model integrated with ARCS categories and the control group students who were applied traditional teaching?

2. Is there a significant difference between the concept perception levels of the experimental group students who were applied cognitive learning model integrated with ARCS categories and the control group students who were applied traditional teaching? 
3. Is there a significant difference between the geometry motivation scores of the experimental group students who were applied cognitive learning model integrated with ARCS categories and the control group students who were applied traditional teaching?

4. Is there a significant difference between the post-test geometry motivation profile scores of the experimental group students who were applied cognitive learning model integrated with ARCS categories and the control group students who were applied traditional teaching?

\section{Method}

\section{Research Model}

The post-test control group model was used in the current study (Buyukozturk, Cakmak, Akgun, Karadeniz, \& Demirel, 2012). The students who were applied the cognitive learning model integrated with ARCS categories selected as the experimental group, and the students who were applied the traditional teaching model selected as the control group accordingly. These groups were formed by a neutral election. Post-test was applied to the both groups after the experiment. It has been accepted that there was no difference between the groups before the experimental study and the groups they were similar to (Karasar, 2012).

\section{Working Group}

The research was conducted with 274 fifth grade students in Luleburgaz district of Kirklareli Province for the academic year 2020-2021. There were 137 participants in the experimental group and 137 participants in the control group in the study. Random sampling was used in the study.

\section{Data Collection Tools}

In the study, Geometry achievement test and Geometry motivation scale were used. The aim of the research to find about the achievement and motivation levels of students about polygons and triangles. Necessary permissions have been obtained from the Ministry of National Education for the practice.

\section{Geometry Achievement Test}

Geometry achievement test was developed by the researcher in a way to cover the achievements of the students on polygons and triangles. The opinions of four mathematics teachers and two faculty members who are experts in the field of mathematics were obtained 
for the reliability of the geometry achievement test. The geometry achievement test was consisted of 20 questions in the test. Each question in the test is a multiple choice with 4 options and has only one correct answer. Each correctly answered of the questions in the test were given 1 point, and ortherwise were given 0 points. The test was administered to 5 th grade students in 30 minutes to answer.

\section{Geometry Concept Perception Test}

The geometry concept perception test was developed by the researcher to measure the students' level of learning concepts about polygons and triangles. The test questions were prepared, concept perception studies on polygons and triangles had been examined in the literature. The expert opinion was received for the prepared geometry concept perception test. The geometry concept perception test consisted of 14 questions. Each question in the test is a multiple choice with 4 options and has only one correct answer. Each correctly answered of the questions in the test were given 1 point, and ortherwise were given 0 points. The test was administered to 5th grade students in 20 minutes to answer.

\section{Geometry Motivation Scale}

Geometry motivation scale was developed by Shia (1998) as a mathematics motivation scale and adapted again by Dede (2003). The scale developed by Dede (2003) was adapted to the geometry motivation scale by the researcher after the necessary permissions. By the researchers geometry motivation scale was redeveloped to determine students' motivation towards geometry. The scale is a 5-point Likert type scale and consists of 26 questions. Thus, scoring process was conducted in the following form: 'Strongly Disagree =1', 'Disagree $=2$ ', 'Undecided = 3', 'Agree $=4$ ' and 'Strongly Agree $=5$ '. Items in the scale were grouped under 3 factors as a result of factor analysis. These factors were named as inadequacy of geometry, geometry effort and fear of geometry. As a result of the reliability analysis of the scale, the Cronbach Alpha Coefficient was calculated as 0.914 for the inadequacy of geometry dimension, 0.755 for the geometry effort dimension and 0.606 for the fear of geometry dimension. The Cronbach Alpha Coefficient for the whole scale was calculated as 0.753 as a result.

\section{Geometry Motivation Profile Scale}

The geometry motivation profile scale was developed by the researchers to determine the motivation profiles of the students towards geometry in accordance with the ARCS Motivation Model strategies. The mathematics motivation profile scale was developed by Dede 
(2003) and was adapted to the geometry motivation profile scale by the researcher after necessary permissions. The scale is a 5-point Likert type scale and consists of 21 questions. The scale was scored as "strongly disagree (1)", "disagree (2)", "undecided (3)", "agree (4)", "strongly agree (5)". Items in the scale were grouped under 2 factors as a result of factor analysis. These factors were named as satisfaction and attention. As a result of the reliability analysis of the scale, the Cronbach Alpha Coefficient was calculated as 0.981 for the satisfaction dimension and 0.520 for the attention dimension. The Cronbach Alpha Coefficient for the whole scale was calculated as 0.954 as a result.

\section{Experimental Operations}

The teaching steps of the cognitive learning model integrated with the developed ARCS categories are given below.

Table 2 Cognitive learning model steps integrated with ARCS categories

\begin{tabular}{|c|c|c|}
\hline Steps & Strategies & Sub-Strategies \\
\hline Introduction & $\begin{array}{c}\text { Strategies } \\
\text { that } \\
\text { provide } \\
\text { and } \\
\text { maintain } \\
\text { attention }\end{array}$ & $\begin{array}{l}\text { Perceptual Arousal } \\
\text { In order to draw the attention of the students to the subject of polygons and triangles, } \\
\text { they were attracted by showing pictures from daily life using visual shapes on the } \\
\text { smart board. In order to keep the students' attention throughout the lesson, non- } \\
\text { functional shapes and expressions related to the subject were avoided. }\end{array}$ \\
\hline & & $\begin{array}{l}\text { Inquiry Arousal } \\
\text { Students were provided with in-depth knowledge of polygons and triangles, solving } \\
\text { questions and receiving feedback on the subject. While providing feedback to the } \\
\text { answers given by asking questions during the lesson, much care was taken to } \\
\text { increase the interest shown in the subject. } \\
\text { Variability } \\
\text { Tutoring was organized in a way to ensure active participation of students in the } \\
\text { lesson, far from being monotonous and without boring the student. Pictures and } \\
\text { visual materials related to the subject were included on the smart board. Much care } \\
\text { was taken to use pictures and visual figures that would appeal to students in daily } \\
\text { life, which would attract the attention and interest of the students. }\end{array}$ \\
\hline Learning & Strategies & \\
\hline Process & $\begin{array}{l}\text { that build } \\
\text { and } \\
\text { maintain }\end{array}$ & $\begin{array}{l}\text { In order for the students to behave comfortably during the lesson and not to show } \\
\text { hesitation in participating in the lesson, much care was taken to use students' names } \\
\text { or some pronouns. In order not to make the subject unfamiliar to the student, the }\end{array}$ \\
\hline
\end{tabular}


the

relevance

Strategies

that

increase

confidence

and

confidence

Evaluation

\section{Satisfaction Intrinsic Reinforcement}

and Students are aimed to gain the skills and abilities in the subject of polygons and strategies

that

provide

satisfaction

pictures and visual figures shown on the smart board were chosen from the classroom environment and the student's immediate environment. With the help of pictures and visual figures, the subject of polygons and triangles was concretized, helping the student to understand the subject more easily.

\section{Goal Orientation}

In the introductory phase of the lesson, the importance and objectives of the lesson were clearly expressed in order to enable the student to achieve the desired level of success, and the importance of the subject was comprehended. In addition, the students were explained in detail what they had to do in order to achieve the aim of the lesson. Later on, suitable environments were created for students to make choices for their own goals.

\section{Motive Matching}

Students were given the opportunity to choose goals that fit the goals they had set. As a result of the achievement tests and concept perception tests, the test questions were answered together and then the students were informed about their performances.

\section{Performance Requirements}

The students were explained in detail about the objectives of the lesson and what they would learn about polygons and triangles. Preliminary information and skills were given to the students, which would require them to have knowledge on subject. At the end of the lecture, students were informed about the content of the tests to be applied. It was stated how many questions were found in the tests and how long it should be completed.

\section{Success Opportunities}

In order to achieve success and avoid boredom at the beginning of the learning process, the teaching of the lesson is planned from easy to difficult and from simple to complex. It was aimed to provide permanent information with reinforcements in the face of the answers given by asking questions to the students.

\section{Personal Control}

An appropriate language was used to encourage students in both their success and failure. Appropriate examples were given for the mistakes students could make about polygons and triangles. triangles. Except for the exercises made during the lecture, practices were included at the end of the subject. The exercises were made to the students as questionsanswers forms as educational games. 


\section{Extrinsic Rewards}

It was said that the students would be motivated in response to the correct answers solved during the lesson. As a feedback to the students who gave wrong answers to the questions, their deficiencies were expressed with appropriate words in order not to lose their interest in the lesson.

\section{Equity}

The lecture was prepared by paying attention to the outcomes in order to be suitable for the aims and objectives of the subject. The applied achievement test and concept perception test were prepared in accordance with the polygons and triangles gains and the questions were arranged to include goals and objectives.

The research conducted took place during Covid-19 Pandemic in the academic year of 2020-2021. In the implementation process of the research, firstly, the choice of subject was decided. Secondly, after the model had been determined, tests were prepared with the help of teachers and experts during the material preparation process. A pilot study was conducted after the necessary permissions had been obtained by the Ministry of National Education before the implementation. Thirdly, after the pilot study, the experimental process was started. In the experimental process, the control group students were taught based on the traditional teaching method, and the experimental group students were taught based on the cognitive learning model integrated with ARCS categories accordingly. After the instruction, geometry achievement test, geometry concept perception test, geometry motivation scale and geometry motivation profile scale were applied to the control and experimental group students. The data were collected as a result of the application were analysed.

\section{Data Analysis}

The data were analysed using the SPSS 21.0 package program. After the experimental procedure, a t-test was conducted to determine whether there was a significant difference in the achievement levels and concept perception levels of the experimental group to which the cognitive learning model integrated with ARCS categories was applied, and the control group, where traditional teaching was applied. The t-test was carried out to determine the significance of the difference between the motivation scale sub-dimensions and the motivation profile scale sub-dimensions of the experimental group to which traditional teaching was applied and of the control group where the cognitive learning model integrated with ARCS categories was applied as a result. 


\section{Findings}

The findings that obtained as a result of the research on statistical analysis of the data collected after the experimental process are included as follows: findings on the geometry achievement levels of the experimental and control group students; findings on the concept perception levels of the experimental and control group students; findings on the motivation levels of the experimental and control group students and findings on the motivation profile levels of the experimental and control group students

Findings on the geometry achievement levels of the experimental and control group students

In Table 3 below, the t-test results of the experimental and control group students' mean scores that obtained from the polygons and triangles post-test are given.

Table 3 t-Test results for the experimental group students' and the control group students' polygons and triangles achievement post-test mean scores

\begin{tabular}{lccccc}
\hline \multicolumn{1}{c}{ Groups } & N & Mean & SS & t & p \\
\hline \hline Experimental & 137 & 0.7325 & 0.11829 & & \\
Group & 137 & 0.4887 & 0.12948 & & 0.000 \\
Control Group & 137.271 & \\
\hline
\end{tabular}

As seen in Table 3, there is a statistically significant difference between the average scores of the experimental and control group students that were obtained from the polygons and triangles post-test. In other words, the polygons and triangles achievement test mean scores of the experimental group students who were applied cognitive learning model integrated with ARCS categories and the control group students who were applied traditional teaching method differ accordingly. When the polygons and triangles achievement post-test mean scores are examined, it is seen that the average score of the experimental group students $(0.7325)$ is higher than the average score of the control group students $(0.4887)$ who were applied traditional teaching method. Therefore the experimental group students who applied the cognitive learning model integrated with the ARCS categories had a higher level of success compared to the control group students who were applied the traditional teaching method.

Findings on the concept perception levels of the experimental and control group students 
Table 4 below shows the results of the t-test for the mean scores of the experimental and control group students that were obtained from the polygons and triangles concept perception post-test.

Table 4 t-Test results for the experimental group students' and control group students' polygons and triangles concept perception post-test mean scores

\begin{tabular}{lccccc}
\hline \multicolumn{1}{c}{ Groups } & N & Mean & SS & t & p \\
\hline \hline Experimental & 137 & 0.7711 & 0.13112 & & \\
Group & 137 & 0.5261 & 0.15708 & & 0.000 \\
Control Group & 137.017 & \\
\hline
\end{tabular}

As seen in Table 4, there is a statistically significant difference between the average scores of the experimental and control group students that were obtained from the polygons and triangles concept perception post-test. In other words, the polygons and triangles concept perception test scores of the experimental group students who were applied cognitive learning model integrated with ARCS categories and the control group students who were applied traditional teaching method differ accordingly. When the mean scores of polygons and triangles concept perception post-test are examined, it is seen that the average score $(0.7711)$ of the experimental group students who were applied the cognitive learning model integrated with the ARCS categories was higher than the average score (0.5261) of the control group students who were applied the traditional teaching method. Hence the experimental group students who were applied the cognitive learning model integrated with the ARCS categories had a higher level of concept perception compared to the control group students who were applied the traditional teaching method.

Findings on the motivation levels of the experimental and control group students

In Table 5 below, $t$ test results for the post-test scores of the sub-dimensions of the geometry motivation scale of the experimental and control group students are given. 
Table 5 t-Test results for the post-test mean scores of the sub-dimensions of the geometry motivation scale of the experimental group students and the control group students

\begin{tabular}{|c|c|c|c|c|c|c|}
\hline Factors & Groups & $\mathbf{N}$ & Mean & SS & $\mathbf{t}$ & $\mathbf{p}$ \\
\hline \multirow{2}{*}{$\begin{array}{l}\text { Inadequacy } \\
\text { of Geometry }\end{array}$} & $\begin{array}{l}\text { Experimental } \\
\text { Group }\end{array}$ & 137 & 3.0158 & 1.08477 & \multirow[t]{2}{*}{9.878} & \multirow{2}{*}{0.000} \\
\hline & Control Group & 137 & 4.0122 & 0.46602 & & \\
\hline \multirow{2}{*}{$\begin{array}{l}\text { Geometry } \\
\text { Effort }\end{array}$} & $\begin{array}{l}\text { Experimental } \\
\text { Group }\end{array}$ & 137 & 2.6606 & 0.81391 & \multirow{2}{*}{-0.542} & \multirow{2}{*}{0.589} \\
\hline & Control Group & 137 & 2.6104 & 0.71664 & & \\
\hline \multirow{2}{*}{$\begin{array}{l}\text { Fear of } \\
\text { Geometry }\end{array}$} & $\begin{array}{l}\text { Experimental } \\
\text { Group }\end{array}$ & 137 & 3.4015 & 1.06115 & \multirow[t]{2}{*}{2.814} & \multirow[t]{2}{*}{0.005} \\
\hline & Control Group & 137 & 3.7056 & 0.68845 & & \\
\hline
\end{tabular}

As seen in Table 5, there is no significant difference between the geometry effort subdimension scores of the control group and experimental group students ( $p>0.05$ ). However, there was a significant difference between the inadequacy of geometry and fear of geometry sub-dimension scores of the control group and experimental group students $(\mathrm{p}<0.05)$. The students in the control group who used the traditional teaching method had higher selfinadequacy towards the geometry lesson and had higher fears regarding the geometry lesson compared to the experimental group students who were applied the cognitive learning model integrated with ARCS categories.

Findings on the motivation profile levels of the experimental and control group students

In Table 6 below, $t$ test results for the post-test scores of the sub-dimensions of the geometry motivation profile scale of the experimental and control group students are given.

Table 6 t-Test results for the post-test mean scores of the sub-dimensions of the geometry motivation profile scale of the experimental group students and the control group students

\begin{tabular}{|c|c|c|c|c|c|c|}
\hline Factors & Groups & $\mathbf{N}$ & Mean & SS & $t$ & $\mathbf{p}$ \\
\hline \multirow{2}{*}{ Satisfaction } & $\begin{array}{l}\text { Experimental } \\
\text { Group }\end{array}$ & 137 & 2.8913 & 1.35739 & \multirow{2}{*}{11.082} & \multirow{2}{*}{0.000} \\
\hline & $\begin{array}{l}\text { Control } \\
\text { Group }\end{array}$ & 137 & 4.2594 & 0.48129 & & \\
\hline \multirow{2}{*}{ Attention } & $\begin{array}{l}\text { Experimental } \\
\text { Group }\end{array}$ & 137 & 2.8710 & 0.89502 & \multirow{2}{*}{-3.121} & \multirow{2}{*}{0.002} \\
\hline & $\begin{array}{l}\text { Control } \\
\text { Group }\end{array}$ & 137 & 2.5564 & 0.76557 & & \\
\hline
\end{tabular}

As seen in Table 6, there is a significant difference between the satisfaction and attention sub-dimension scores of the students in the control group and the experimental group $(\mathrm{p}<0.05)$. 
It was observed that the experimental group students who were applied the cognitive learning model integrated with the ARCS categories paid more attention to the geometry lesson than the control group students who used the traditional teaching method. In addition, the satisfaction scores of the students in the control group using the traditional teaching method for the geometry lesson were higher than the experimental group students who were applied the cognitive learning model integrated with ARCS categories. In other words, the students in the control group had more positive thoughts based on their experiences compared to the students in the experimental group as a result.

\section{Conclusion and Discussion}

When the findings regarding the achievement levels of the students participating in the study about polygons and triangles were examined, it was found that the achievement post-test scores of the experimental and control groups differed significantly in favour of the experimental group. While the polygons and triangles achievement post-test mean scores of the experimental group students were 0.7325 , the polygons and triangles achievement post-test mean scores of the control group students were found to be 0.4887 . It means that the experimental group students who were applied the cognitive learning model approach integrated with ARCS categories were more successful in the learning of polygons and triangles than the control group students who were applied traditional teaching. In addition, it can be said that the cognitive learning model integrated with the ARCS categories is effective in learning the subject. It should be noted that similar results can also be seen in the study conducted by Dede (2003). Dede (2003) investigated whether the concept of variable had an effect on student achievement of the approach based on ARCS Motivation Model and Item Representation Theory, and as a result of the research, a significant difference was found in favour of the experimental group in terms of students' learning levels. Moreover, Balantekin (2014) investigated student success according to the constructivist learning approach that was designed based on the ARCS Motivation Model and concluded that the ARCS Motivation Model had an important effect on increasing student success. Similarly, Yesiltepe (2019) and Narmanli (2019), in their studies, examined student success by applying a teaching that was designed according to the ARCS Motivation Model and the results of their studies showed that the model increased academic success accordingly. These studies are in line with the findings of the current study. 
When the findings regarding the concept perception levels of the students participating in the study about polygons and triangles were examined, a significant difference was found in the concept perception post-test scores of the experimental and control groups in favour of the experimental group. While the polygons and triangles concept perception post-test mean scores of the experimental group students were 0.7711 , the polygons and triangles concept perception post-test mean scores of the control group students were 0.5261. As a result, it can be said that the experimental group students who were applied the cognitive learning model approach integrated with ARCS categories had higher concept perception levels about polygons and triangles compared to the control group students who were applied traditional teaching. In other words, the cognitive learning model integrated with ARCS categories has shown positive results in students' comprehension of the subject. Considering the findings of the geometry lesson motivation levels of the students participating in the study, a statistically significant difference was found in the mean scores of the geometry motivation scale sub-dimensions of the inadequacy of geometry and fear of geometry. While the mean score regarding the inadequacy of geometry subscale was 3.0158 for the experimental group students, it was calculated as 4.0122 for the control group students. The control group students studying with the traditional teaching method considered themselves insufficient in the geometry lesson. While the mean score regarding the fear of geometry subscale was 3.4015 for the experimental group students, it was calculated as 3.7056 for the control group students. As a result, the control group students who study with the traditional teaching method have more fear of the geometry lesson compared to the experimental group students who study with the cognitive learning model approach integrated with ARCS categories. Similarly, Balantekin and Bilgin (2017) concluded that the ARCS Motivation Model affects students' motivation levels. Narmanli (2019) reached similar findings as well. In his study, he examined the effect of the ARCS Motivation Model on the motivation level of the students, and the model increased the motivation of the students and it actively engaged students in the process and therefore he figured out that the students' attention was protected throughout the process. Also, there are studies that conclude the ARCS Motivation Model has no effect on student motivation. For example, Dede's (2003) study examined the motivational effect of the ARCS Motivation Model on students' mathematics lesson and found that there was no significant difference among the motivation post-test scores of the students. Dede's study findings showed that the reasons for this could be the characteristics of the school where the application was made, the surrounding conditions and the personal characteristics of the teacher who was responsible as well. On the other hand, Çalışkan (2017) determined that the ARCS Motivation Model did not make a 
significant difference among students' motivation post-test scores. Furthermore, Yesiltepe (2019) used the ARCS Motivation Model to investigate the effect on students' motivation to learn science, and as a result, he found out that there was no statistically significant effect on students' motivation to learn science.

According to the findings related to the effect of students' geometry course motivation profile, a statistically significant difference was found in the mean scores of the geometry motivation profile scale sub-dimensions of satisfaction and attention. While the mean score regarding the satisfaction subscale was 2.8913 for the experimental group students, it was calculated as 4.2594 for the control group students. According to the research result, the satisfaction scores of the control group students studying with the traditional teaching method for the geometry lesson were higher. While the average score regarding the attention dimension, the other sub-dimension, was 2.8710 for the experimental group students, it was calculated as 2.5564 for the control group students. The research result shows that the average scores of the experimental group students studying with the cognitive learning model approach integrated with ARCS categories is higher than the control group students studying with the traditional teaching method. In other words, it can be said that the experimental group students were more successful than the control group students in sustaining their attention in the lesson. On the other hand, Dincer (2020) conducted a meta-analysis study examining the relationship between motivation and materials designed according to the ARCS model and he concluded that the materials had a positive effect on motivation. That is, he found out that the motivation of the students was increased with the increase in the duration of the use of the material. Chang, $\mathrm{Hu}$, Chianh, and Lugmayr (2019) applied the ARCS Motivation Model to examine students' willingness and validate their learning skills through mobile augmented reality (MAR) technology. Hence, effective learning indicators such as learning interest, confidence and satisfaction were used to evaluate students' learning motivation using MAR technology. As a result of their study, it was concluded that the experimental group using MAR technology as a learning aid showed a higher learning activity compared to the control group. Last but not least, Yuncu Kurt and Kecik (2017) examined the effects of the ARCS Motivation Model on the motivation of university preparatory students and concluded that the ARCS model had a positive effect on students' course motivation. Moreover, Koon Wah (2015) used Geogebra to integrate attention, relevance, confidence and satisfaction strategies, and investigated the effects on the motivation and success of high school students. He determined a significant difference in the motivation and success of the students before and after the instruction as a result. The 
other words, Tandogan (2019) investigated the effectiveness of teaching materials that were developed according to the ARCS Motivation Model, along with augmented reality (AR) on students' vocabulary success and motivation in the field of engineering. It was concluded that the experimental group performed significantly better than the control group in vocabulary achievement tests. In addition, it has been determined that when teaching materials are presented with mobile AR applications and developed according to the ARCS Motivation Model, it can be effective for vocabulary success, motivation and positive perceptions of students. It is worth bearing in mind that these studies show that the model has a positive effect on motivation and is consistent with the findings of the current study.

To sum up, the findings of the study indicated that the cognitive learning model approach integrated with ARCS categories applied to the fifth grade students in teaching the subject of polygons and triangles was more effective at the learning level compared to the current teaching method, and it should be noted that it had a positive effect on motivation. Since the subject of polygons and triangles includes many mathematical concepts and geometric elements, providing and maintaining student motivation by using the cognitive learning model integrated with ARCS categories in an educational environment, and addressing the ignored motivation dimension highlighting the importance of the study, they will contribute to the literature and theory accordingly.

\section{Suggestions}

Considering the results of the research, it can be recommended for educators and researchers to do more studies on geometry subject since working examples of the model are rare. The effect of the model can be investigated by applying it to different lessons and different grade levels. In the present study, the effect of cognitive learning model integrated with ARCS categories on students' learning levels and motivation was examined. Apart from these variables, the effect of the model can be investigated by considering different variables such as different attitude and permanence of knowledge. The model can be adapted to different subjects in the field of geometry as well.

\section{Notes}

Ethical approval for this study was obtained from Balıkesir University Science and Engineering Ethics Committee (29.06.2020 / 25040). 


\section{References}

Balantekin, Y. (2014). ARCS motivasyon modeline göre tasarlanan yapılandırmacı öğrenme yaklaşımının öğrencilerin motivasyonlarına, tutumlarına ve akademik başarılarına etkisi. Doktora tezi, Uludağ Üniversitesi, Bursa.

Bernabeu, M., Moreno, M. and Llinares, S. (2021). Primary school students' understanding of polygons and the relationships between polygons. Educational Studies in Mathematics, 106, 251-270.

Budak, S. (2010). Çokgenler konusunun bilgisayar destekli öğretiminin 6.sınıf öğrencilerinin akademik başarılarına ve bilgisayar destekli geometri ögretimine yönelik tutumlarına etkisi. Yüksek lisans tezi, Eskişehir Osmangazi Üniversitesi, Eskişehir.

Büyüköztürk, Ş., Çakmak, E.K., Akgün, Ö.E., Karadeniz, Ş. ve Demirel, F. (2012). Bilimsel araştırma yöntemleri. Ankara: Pegem Akademi Yayınları.

Cevher, T. Y. (2019). Öge Gösterim kuramına dayalı kavram ögretiminin ortaokul 7. Sinıf ögrencilerinin Türkçe dersindeki başarılarına etkisi. Doktora tezi, Trabzon Üniversitesi, Trabzon.

Chang, Y. S., Hu, K. J., Chianh, C. W. and Lugmayr, A. (2019). Applying mobile augmented reality (AR) to teach interior design students in layout plans: Evaluation of learning effectiveness based on the ARCS Model of learning motivation theory. Sensors (Basel), $20(1), 105$.

Dede, Y. (2003). ARCS Motivasyon Modeli ve Öğe Gösterim Teorisi’ne dayalı yaklaşımın ögrencilerin değişken kavramını ögrrenme düzeylerine ve motivasyonlarına etkisi. Doktora tezi, Gazi Üniversitesi, Ankara.

Dinçer, S. (2020). The effects of materials based on ARCS Model on motivation: A metaanalysis. Illköğretim Online, 19(2), 1016-1042.

Eryılmaz, S. (2009). Web ortamında öge gösterim kuramına göre tasarlanan kavram ögretiminin, öğrencilerin akademik başarılarına, tutumlarına ve öğrenmenin kalıcılı̆̆ına etkisi. Doktora tezi, Gazi Üniversitesi, Ankara.

Fujita, T. (2012). Learners'level of understanding of inclusion relations of quadrilaterals and prototype phenomenon. The Journal of Mathematical Behaviour, 31, 60-72.

Karasar, N. (2012). Bilimsel araştırma yöntemleri (24. Bs.). Ankara: Nobel Yayınevi.

Keller, J. M. (1983). Motivational Design Of Instruction. In C. M. Reigeluth (Ed.), Instructional Design Theories And Models: An Overview Of Their Current Status. Hillsdale NJ: Lewrance Erlbaum Associates. 
Keller, J. M. and Kopp, T. W. (1987). An application of the ARCS model of motivational design, in C.M. Reigeluth (Ed.), Instructional Design Theories and Models: An Overview of Their Current Status, Hillsdale: Lawrance Erlbaum Associates, USA.

Keller, J. M. (1987a). Development and use of ARCS model in instructional design. Journal of Instructional Development, 10 (3), 2-10.

Keller, J. M. (1987b). Strategies for stimulating the motivation to learn, performance and instruction, $26(8), 1-7$.

Kurt, M. (2012). ARCS motivasyon modeline göre harmanlanmış ögretimin, ilköğretim 6. sinıf bilişim teknolojileri dersinde öğrenci başarısına etkisi. Yüksek lisans tezi, Gazi Üniversitesi, Ankara.

Laçinbay, K. ve Yılmaz, M. (2019). Görsel sanatlar ders materyali geliştirme sürecinde ARCS motivasyon modelinin kullanımı. Kastamonu Eğitim Dergisi, 28 (1), 468-481.

Merrill, D. M. (1983). Component Display Theory. (Ed. Reigeluth C.). Instructional Design Theories and Models. Hillsdale, NJ: Erlbaum Associates.

Merrill, D. M. (1987a). A Lesson Based On The Component Display Theory. (Ed. 103 Reigeluth, C.). Instructional Theories In Action: Lessons Illustrating Selected Theories and Models. Hillsdale, New Jersey: Erlbaum Associates.

Merrill, D. M. (1987b). The new component design theory: Instructional design for courseware authoring. Instructional Science, 16, 19 -34.

Narmanlı, E. (2019). ARCS motivasyon modelinin sosyal bilgiler öğretiminde öğrencilerin akademik başarılarına ve motivasyon düzeylerine etkisi. Yüksek lisans tezi, Atatürk Üniversitesi, Erzurum.

Reigeluth, C. M. (1983). Instructional Desing: What Is It and Why Is It? Instructional Design Theories and Models. (Ed: C. M. Reigeluth.) Hillsdale, NJ: Lawrance Erlbaum Associates.

Reigeluth, C. M. (1987). Instructional Theories in Action, Hillsdale, NJ: Lawrence Erlbaum Associates, Publishers.

Shia, R. (1998). Running head: Academic intrinsic and extrinsic motivation and metacognition. assessing academic intrinsic motivation: A look at student. Goals And Personal Strategy. www.cet.edu/research/papers/motivation/motivation.pdf.

Tahiroğlu, M. (2015). ARCS motivasyon modeli'nin ilkokul 4. sınıf öğrencilerinin sosyal bilgiler dersine yönelik motivasyonlarına ve başarı düzeylerine etkisi. Journal of World of Turks, 7(2), 261-285. 
Tandoğan, B. (2019). Investigating The Effectiveness Of ARCS Based Instructional Materials Enhanced With Augmented Reality On Esp Vocabulary Achievement And Motivation. Degree master thesis, Middle East Technical University, Ankara.

Yeşiltepe, K. (2019). ARCS motivasyon modelinin fen bilimleri dersi güneş sistemi ve tutulmalar ünitesinde ögrencilerin akademik başarısı ve motivasyonuna etkisi. Yüksek lisans tezi, Niğde Ömer Halisdemir Üniversitesi, Niğde.

Yuncu Kurt, P. ve Keçik, İ. (2017). The effects of ARCS motivational model on student motivation to learn English. Europen Journal of Foreign Language Teaching, 2(1), 2244. 